\title{
High-Intensity Interval Training Beneficial Effects in Diet- Induced Obesity in Mice: Adipose Tissue, Liver Structure, and Pancreatic Islets
}

\author{
Efectos Beneficiosos del Entrenamiento con Intervalos de Alta Intensidad en la Obesidad \\ Inducida por Dieta en Ratones: Tejido Adiposo, Estructura del Hígado e Islotes Pancreáticos
}

Victor F. Motta*; Marcia B. Aguila* \& Carlos A. Mandarim-de-Lacerda*

MOTTA, V. F.; AGUILA, M. B. \& MANDARIM-DE-LACERDA, C. A. High-intensity interval training beneficial effects in dietinduced obesity in mice: adipose tissue, liver structure, and pancreatic islets. Int. J. Morphol., 34(2):684-691, 2016.

SUMMARY: The study aimed to evaluate the impact of high-intensity interval training (HIIT) on adipose tissue, pancreatic islets and liver in mice fed high-fat diet. C57BL/6 male mice were fed one of two diets: standard chow (Lean group - LE) or a high-fat diet (Obese group - OB). After the first 12-weeks, the animals were divided into non-trained (LE-NT and OB-NT), trained groups (LE$\mathrm{T}$ and OB-T), and started the exercise protocol. The HIIT protocol in the trained animals (LE-T and OB-T) compared to their counterparts (LE-NT and OB-NT) led to a reduction in size of the pancreatic islets (LE-T vs. LE-NT -40 \%, OB-T vs. OB-NT -22 \%) and to an increase in insulin immunodensity in pancreatic islet (LE-T vs. LE-NT $+35 \%$, OB-T vs. OB-NT +31 \%). Apart from the above results, in adipose tissue, a decrease of the diameter of adipocytes (LE-T vs. LE-NT -23 \%, OB-T vs. OB-NT -12 \%), a reduction in adiposity index (LE-T vs. LE-NT -49 \%, OB-T vs. OB-NT -24 \%) and in the liver, a decrease in the context of hepatic steatosis (LE-T vs. LE-NT $-57 \%$, OB-T vs. OB-NT -77\%). These metabolic changes characterize a benefits performance of the HIIT protocol in swimming. HIIT is able to mitigate the bad effects caused by high-fat diet, even with continued intake of this diet in an animal model. HIIT has the advantage of requiring only a few weekly sessions with short duration in each session. These benefits are important to motivate people who nowadays live with a lack of time condition for these activities.

KEY WORDS: HIIT; Obesity; Insulin Resistance; Hepatic Steatosis; Stereology.

\section{INTRODUCTION}

It is a challenge for society controlling the increase of issues associated with obesity in the population, such as insulin resistance (IR) / type 2 diabetes mellitus (DM2), arterial hypertension, dyslipidemia and nonalcoholic fatty liver disease (NAFLD), which is designated as metabolic syndrome (MetS) (Shamseddeen et al., 2011). Therefore, changes in lifestyle culminate with increased physical activity and healthy habits in nutrition, promoting weight loss and improving metabolic parameters (Marques et al., 2010; Schultz et al., 2012; Centis et al., 2013).

High-intensity interval training (HIIT) is a form of interval training that prioritizes short and intense periods interspersed with short recovery periods. The main goal of HIIT is to develop benefits for the cardiovascular system (Chrysohoou et al., 2015; Scharf et al., 2015). This type of training improves physical condition and capacity, fostering an improvement in glucose metabolism and burning fat reserves (Motta et al., 2015; Smith-Ryan et al., 2015). Both the HIIT and moderate-intensity continuous exercise training (MICT) led to similar effects on inflammatory markers (nesfatin-1, interleukin-6, and tumor necrosis factor alpha), and insulin resistance in men who are overweight, but the HIIT seems to have better anorectic effects (as indicated by nesfatin) compared with MICT (Ahmadizad et al., 2015). HIIT significantly increases cardiorespiratory fitness by almost double that of MICT in patients with lifestyle-induced chronic diseases (Weston et al., 2014). In addition, HIIT may provide a more robust stimulus than MCT for early exercise training adaptations in patients with heart failure and preserved ejection fraction (Angadi et al., 2014), and HIIT significantly reduces body mass, blood pressure and oxidative stress in menopause (Pimenta et al., 2015). 
The current study was undertaken to investigate the effects of HIIT in diet-obese mice, evaluating the structural alterations of the adipose tissue, pancreatic islets and beta cells, and the liver steatosis that accompanies NAFLD.

\section{MATERIAL AND METHOD}

Animals and diets: Handling protocols and experiments were submitted to the Ethics Committee on Animal Experiments of the State University of Rio de Janeiro (CEA/041/2012). All procedures were performed in accordance with the precepts of the "Guide for the use of laboratory animal care" (NIH Publication No. 85-23, revised in 1996, USA). The animals were kept in a system with ventilated caging (Nexgen Ecoflo, Allentown, Inc., USA) and controlled temperature $\left(21 \pm 2{ }^{\circ} \mathrm{C}\right)$, humidity $(60 \pm 10 \%)$, and a light/dark cycle (12 h light-dark).

Three-month-old male C57BL/6 mice $(n=40)$ were fed one of two experimental diets during the duration of the experiment: standard chow (lean animals, LE, $76 \%$ calories from carbohydrates, $10 \%$ calories from fat, and $14 \%$ calories from protein) or a high-fat diet (obese animals, OB, $36 \%$ calories from carbohydrates, $50 \%$ calories from fat, and $14 \%$ calories from protein). The diets were manufactured in accordance with the American Institute of Nutrition's recommendations (AIN-93) (Reeves et al., 1993), and the amounts of vitamins and minerals are identical in both diets. The experimental diets were produced by PragSolucoes (Jau, SP, Brazil) and stored at $4{ }^{\circ} \mathrm{C}$.

After 12 weeks, the animals were divided into four groups ( $\mathrm{n}=10$ per group) and started an exercise protocol for an additional 12 weeks: non-trained animals (LE-NT and OB-NT) and trained animals (LE-T and OB-T). The length of the experiment was 24 weeks.

High-intensity interval training protocol (HIIT): Animals were adapted to the pool (15 min/day for two days) without load before the start of the HIIT protocol (a glass tank was $40 \times 30 \times 80 \mathrm{~cm}$ with a controlled water temperature, $32 \pm 2{ }^{\circ} \mathrm{C}$ ). The NT animals were submitted to an environment similar to the $\mathrm{T}$ animals in the pool. The maximum swimming time (MST) was the time the animal was more than $10 \mathrm{~cm}$ below waterline incapable of returning to the surface of the water to breathe after $10 \mathrm{~s}$ (Motta et al.). We conducted a maximum number of series (20 s of active exercise with $10 \%$ of the body mass increment in the tail with $10 \mathrm{~s}$ of passive recovery). Thus, for the experimental protocol, $50 \%$ of this maximum number of series determined in the test was used, and the exercise protocol was performed three times a week for 12 weeks. Every two weeks, the percentage of the incremental load was gradually increased, growing from 10 to $15 \%$.

Euthanasia: The day after the last exercise, after a fast of $6 \mathrm{~h}$, the animals were deeply anesthetized (intraperitoneal sodium pentobarbital, $150 \mathrm{mg} / \mathrm{kg}$ ). Blood samples were obtained by cardiac puncture and centrifuged at $120 \mathrm{~g}$ for $15 \mathrm{~min}$ at room temperature, and the plasma was stored at $-80{ }^{\circ} \mathrm{C}$ until assayed.

We studied the inguinal fat pad (subcutaneous fat located between the lower part of the rib cage and the midthigh) and the intra-abdominal fat pad (a retroperitoneal fat connected to the posterior abdominal wall near the kidneys plus epididymal fat located in the lower part of the abdomen and connected to the epididymis in males). The fat pads were dissected and weighed, and the epididymal fat was then kept in freshly prepared fixative (formaldehyde $4 \% \mathrm{w} / \mathrm{v}, 0.1 \mathrm{M}$ phosphate buffer $\mathrm{pH}$ 7.2) for light microscopy. Additionally, the adiposity index was determined as the ratio between the sum of the fat masses divided by the total $\mathrm{BM}$, presented as a percentage (Barbosa-da-Silva et al., 2012).

Adipocytes, liver steatosis, and pancreatic islets: Fragments of the epididymal fat pad, the pancreas and the liver were obtained and fixed in freshly prepared fixative for $48 \mathrm{~h}$ at room temperature $(1.27 \mathrm{M}$ formaldehyde in 0.1 M sodium phosphate buffer, $\mathrm{pH}$ 7.2), and then embedded in Paraplast Plus (Sigma-Aldrich, St. Louis, MO, USA). The blocks were exhaustively cut with a nominal thickness of five micrometers and stained with hematoxylin and eosin or immunostained as detailed below.

The adipocytes and islets were measured in their equatorial diameters in digital images obtained with a Leica DMRBE microscope (Wetzlar, Germany) and an Infinity 1-5C digital camera (Lumenera Co., Ottawa, ON, Canada). The image analysis used the Image-Pro Plus software (version 7.03 for Windows, Media Cybernetics, Rockville, MD, USA) as described elsewhere (Fernandes-Santos et al., 2013), in a minimum of 50 adipocytes or islets per animal, in nonconsecutive slices.

The liver steatosis was quantified by 'pointcounting' on digital images, as described previously (Aguila et al., 2003; Catta-Preta et al., 2011). A 49-points testsystem (PT) produced by STEPanizer web-based software was used (Tschanz et al., 2011). The volume density of the steatosis $(\mathrm{Vv}[$ liver, steatosis $])=\mathrm{Pp}[$ liver, steatosis $] /$ 
PT, where Pp[liver, steatosis] was the number of points that hit the fat deposits in the hepatocytes.

Beta-cell immunohistochemistry: Antigen retrieval was performed with citrate buffer, $\mathrm{pH} 6.0$; endogenous peroxidase was quenched with $3 \%$ hydrogen peroxide, and nonspecific binding was inhibited by phosphate-buffered saline $/ 5 \%$ bovine serum albumin. Pancreas sections were incubated with anti-insulin antibody (A0564, DAKO, Glostrup, Denmark), and the reaction was amplified by a biotin-streptavidin system (K0679; Universal DakoCytomation LSAB + Kit, Peroxidase, Glostrup, Denmark). The reaction was visualized after incubation with 3,3'-diaminobenzidine tetrachloride (K3466, DakoCytomation), and sections were counterstained with Mayer hematoxylin. The beta-cell immunodensity was assessed with insulin-positive areas of the islets and expressed as a percentage of the islet (Image-Pro Plus version 7.05, Media Cybernetics, Silver Spring, MD, USA). Selecting the range of pixels that encompassed the object of interest generated a new black-and-white image, where the areas of interest are shown in white color, represent the immunostained cells with insulin and the black areas represent the remaining tissue (Fernandes-Santos et al.).

Data analysis: Data are reported as the mean and the respective standard error of the mean. All samples were tested for normality and homogeneity of the variances; the differences among groups were then tested by one-way ANOVA and the posthoc test of Holm-Sidak (Graph Pad Prism version 6.07 for Windows, San Diego, California, USA). A pvalue $<0.05$ was considered statistically significant.

\section{RESULTS}

Adipocyte diameter and adiposity index: The $\mathrm{OB}$ group showed greater adipocytes compared to the LE group ( $85 \%$; $p$ <.001) until the beginning of the exercise protocol. At the end of the HIIT protocol, adipocytes from trained groups were lower when compared with their non-trained counterparts, respectively (LE-T - $23 \%$; $\mathrm{p}<0.01$ and OB-T -12 $\%$; $\mathrm{p}<0.01)$. The adiposity index was greater in the OB-NT group by $137 \%$ compared to the LE-NT group ( $\mathrm{p}<0.001$ ). In addition, the adiposity index was $49 \%$ smaller in the LE-T group $(\mathrm{p}<0.001)$,

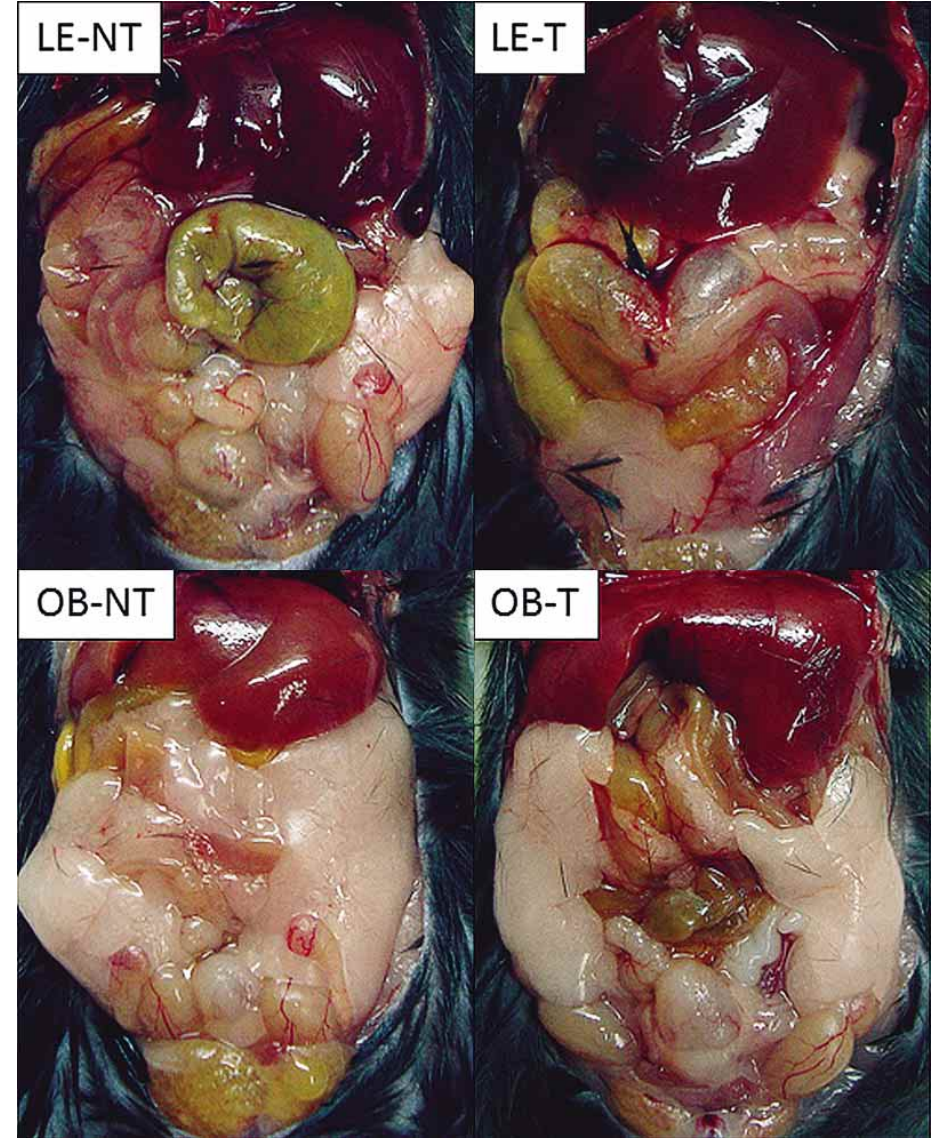

Fig. 1. Internal organs and fat accumulation in the animals. (A) LE-NT, (B) LE-T, (C) OB-NT and (D) OB-T.

and $24 \%$ smaller in the OB-T group ( $\mathrm{p}<0.001)$ compared to the NT counterparts (Figs. 1 and 2).

Hepatic steatosis: An excessive accumulation of fat in the liver (steatosis) of the animals in OB group, when compared to LE group, was observed. At the end of the experiment, trained animals obtained a reduction in this percentage of hepatic steatosis (LE-T $-57 \%$; P <0.05 and OB-T -77 \%; P <0.001), respectively when compared to the non-trained counterparts (Fig. 3).

Pancreatic islets: The OB group showed an increase of the islet cross-sectional diameter by $46 \%$ in relation to the LE groups (p $<0.01$ ), which was associated with an increase of $119 \%$ of the immunodensity for insulin in the islets of the OB group compared to that in the LE group $(\mathrm{p}<0.001)$. The HIIT lead to a reduction in the diameter of the islets in the LE-T (by $40 \%$, p <0.01) and OB-T-groups (by $22 \%, \mathrm{p}<0.01$ ) compared with those of the NT counterparts. The HIIT also improves the insulin immunodensity in the islets by $35 \%$ in the LE-T group ( $\mathrm{p}<0.001)$ and by $31 \%$ in the OB-T group ( $\mathrm{p}<0.001)$ compared with those of the NT counterparts (Fig. 4). 
Fig. 2. Adipose tissue. (A) size distribution of adipocytes in the groups; (B) adiposity index. When indicated, there was a significant difference ( $\mathrm{p} \leq 0.05$ ) compared to $\dagger \mathrm{LE}-\mathrm{NT}, \ddagger \mathrm{LE}-\mathrm{T}$, and $\S$ OB-NT (one-way ANOVA and posthoc test of Holm-Sidak). The photomicrographs (C to F) were stained with hematoxylin and eosin: (C) LENT; (D) LE-T; (E) OB-NT; (F) OB-T.

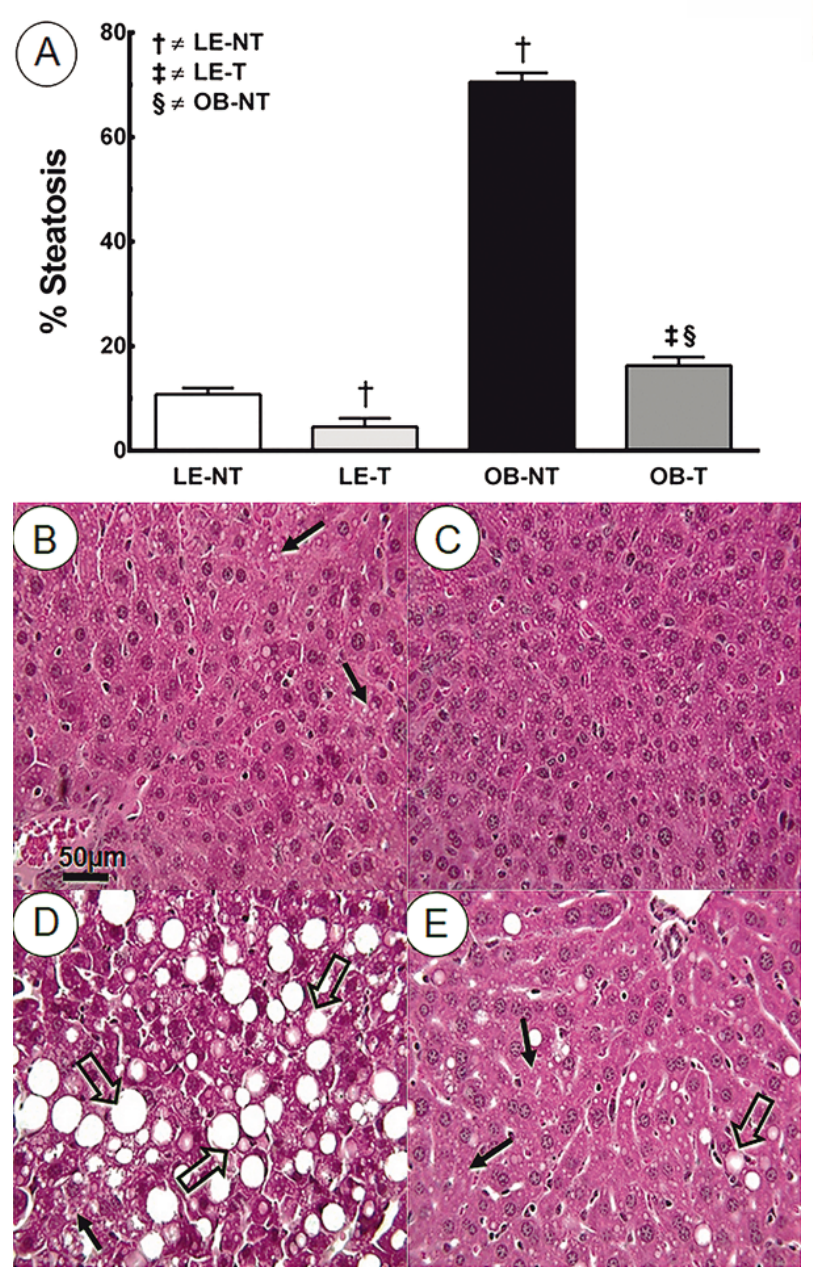

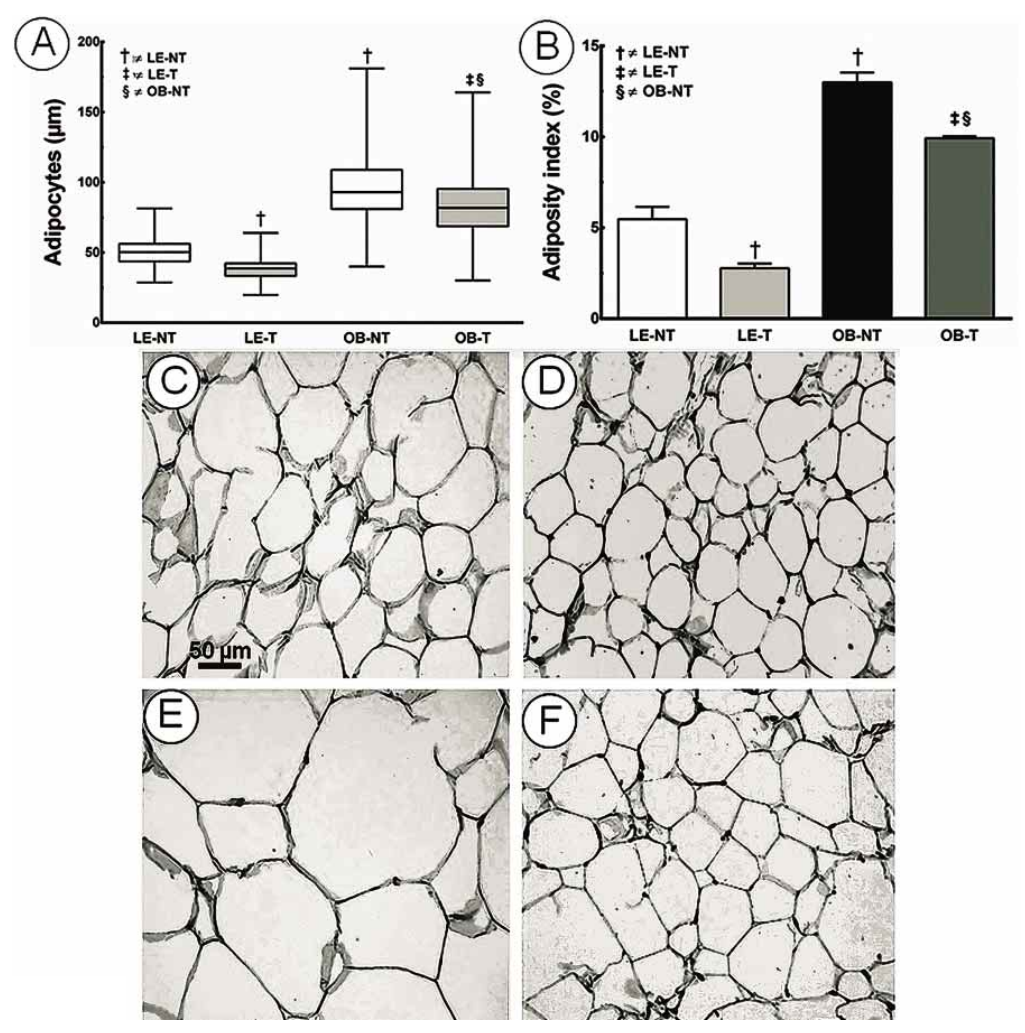

Fig. 3. Hepatic steatosis analysis. (A) volume density of the steatosis (mean and standard error of the mean). When indicated, there was a significant difference $(\mathrm{p}<0.05)$ compared to $\dagger$ LE-NT, $\ddagger$ LE-T, and $\S$ OB-NT (one-way ANOVA and posthoc test of Holm-Sidak). The photomicrographs (stained with hematoxylin and eosin) show macro- (open arrows) and microvesicular (arrows) steatosis (B) LENT (low content of fat in the hepatocytes); (C) LE-T (low content of fat in the hepatocytes); (D) OB-NT (high content of fat in the hepatocytes); (E) OB-T (moderate content of fat in the hepatocytes). 


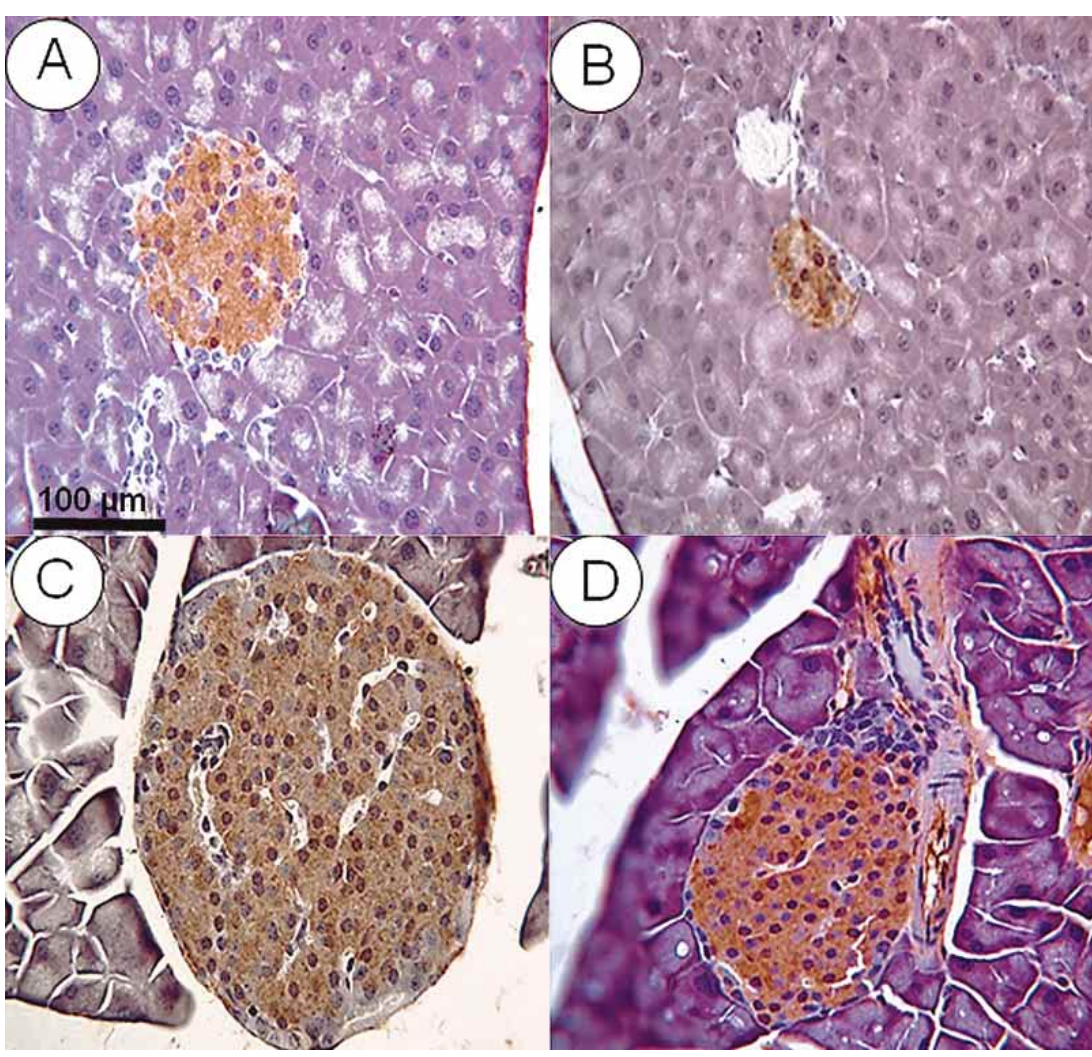

Fig. 4. Insulin immunohistochemistry (beta-cells) in the pancreatic islets: (A) LE-NT group; (B) LE-T group; (C) OB-NT group; (D) OB-T group.

\section{DISCUSSION}

We have chosen the experimental model because their phenotypic susceptibility to the development of components related to the human MetS (Fraulob et al., 2010). The high-fat diet was relevant in increasing the body mass of the animals and causes an adipose tissue hypertrophy, fat accumulation in the liver cells, and changes in carbohydrate metabolism. As we have observed, there are beneficial effects of the exercise training in the animals, even maintaining the excessive consumption of a high-fat diet. The LE group did not show significant changes in the adipocytes and pancreatic islet size and the glucose metabolism while the $\mathrm{OB}$ group showed these alterations. The training protocol led to benefits to the animals, mainly the OB animals.

The development of several co-morbidities, such as IR/DM2 is associated directly with the quality of life and physical inactivity. The goal of the exercise is the recovery of health, changing lifestyle through major metabolic changes, acting as an anti-inflammatory agent (Mei et al., 2011). The HIIT protocol is particularly indicated when the time expenditure is a problem to break the sedentary lifestyle (Drigny et al., 2013).

We know that different types of exercise protocols are beneficial to the fatty liver and insulin resistance (Gauthier et al., 2003; Marques et al.; Schultz et al.). The mechanism by which exercise may lead to the benefits is related to, at least in part, the use of fat as fuel for fat oxidation during exercise (Helge, 2002). In diet-induced obese mice, the exercise combined with a calorie restriction was more significant in reducing adiposity than calorie restriction or just exercise. Dietary restriction and exercise - whatever the type - appear to be an excellent strategy for the control of obesity (Aucott et al., 2004; Poobalan et al., 2004).

The composition of the adipose tissue is a determinant of metabolic activity and responds to environmental changes (Yang \& Smith, 2007). In the current study, we saw a greater number of smaller adipocytes in the trained mice, but a lesser number of large adipocytes in the untrained mice, which could be explained because the increased lipolysis, and attenuated lipogenesis, due to the exercise training.

The high-fat diet was associated with an increased visceral adiposity in the non-trained animals. In the trained animals, HIIT was effective in reducing the visceral adiposity. The lipoprotein lipase activity increases with exercise and is responsible for releasing the fatty acids of lipoproteins, promoting an imbalance between the consumption of high-fat diet and the effects caused by exercise (Schrauwen \& Westerterp, 2000). Options for the control of obesity and reduced hepatic steatosis in the obese population may be complemented with different types of exercise protocols (Tock et al., 2006). As demonstrated, HIIT has been effective in reducing hepatic steatosis in obese animals.

Hyperinsulinemia associated with insulin resistance may lead to the development of type 2 diabetes (Ferrannini, 2006). The consumption of high-fat diet is associated with an excessive level of glucose and free fatty acids worsen the state of insulin resistance by increasing lipolysis and secretion of insulin. In addition, sedentary lifestyles can also lead to the 
development of type 2 diabetes (Bassuk \& Manson, 2005). Even without body mass loss, exercise training is able to improve insulin sensitivity. One of the positive effects of exercise is linked with the increase in glucose transporters (GLUT4 mostly) in skeletal muscle (Younossi, 2008; Little et al., 2011). The exercise training is also able to enhance the insulin action in the liver besides reducing glycogen forcing fatty acids to be used as the main energy substrate for skeletal muscle. Moreover, during the recovery period, glycerol is mightily needed for reconstruction (Gauthier et al., 2004).

The effect caused by exercise interacts with beta cells fat metabolism. An abnormal accumulation of fat in the beta cells has been implicated in the pathogenesis of functional islet failure and cell death in type 2 diabetes incident. The fatty acid excess in association with hyperglycemia is toxic to pancreatic islets (El-Assaad et al., 2003). Moreover, the fatty acids are essential to the insulin secretion stimulated by glucose. Changes in the metabolism of fatty acids may be involved in the physiological adaptations of pancreatic islets in response to the effects caused by physical exercise
(Lamontagne et al., 2007). In the present study, the reduction in the islet size and immunodensity of beta cells in the trained mice was significant in comparison with non-trained animals.

Finally, diet-induced obese mice develop manifestations compatible with the human MetS. The HIIT protocol brought benefits in reducing IR and hepatic steatosis. The findings reinforce the importance of HIIT (swimming) as a non-pharmacological approach to the control of adiposity, insulin resistance, and hepatic steatosis.

\section{ACKNOWLEDGMENTS}

This research was supported by grants from the Conselho Nacional de Ciência e Tecnologia from Brazil (grant \# 302.154/2011-6, to CML), and Fundação do Amparo à Pesquisa do Rio de Janeiro from Rio de Janeiro State (grant \# E-26/102.944/2011, to CML). The authors are grateful to Michele Soares for technical assistance.

MOTTA, V. F.; AGUILA, M. B. \& MANDARIM-DE-LACERDA, C. A. Efectos beneficiosos del entrenamiento con intervalos de alta intensidad en la obesidad inducida por dieta en ratones: tejido adiposo, estructura del hígado e islotes pancreáticos. Int. J. Morphol., 34(2):684-691, 2016.

RESUMEN: El objetivo fue evaluar el impacto del entrenamiento con intervalos de alta intensidad (EIAI) sobre el tejido adiposo, el hígado y los islotes pancreáticos en ratones alimentados con dieta alta en grasas. Ratones C57BL/6, machos fueron alimentados con una de dos dietas: dieta estándar (grupo magro - MA) o una dieta alta en grasas (grupo obeso - OB). Después de las primeras 12 semanas, los animales fueron divididos en dos grupos, no entrenados (MA-NE y OB-NE) y grupos entrenados (MA-E y OB-E), y comenzaron el protocolo de ejercicio. El protocolo de IEAI en los animales entrenados (MA-E y OB-E) en comparación con sus contrapartes (MA-NE y OB-NE) condujo a una reducción en el tamaño de los islotes pancreáticos (MA-E vs. MA-NE - $40 \%$, OB-E vs. OB-NE $22 \%$ ) y al aumento de la inmunodensidad de insulina en los islotes pancreáticos (MA-E vs. MA-NE $+35 \%$, OB-E vs. OB-NE +31 \%). Además, en el tejido adiposo se detectó una disminución del diámetro de los adipocitos (MA-E vs. MA-NE - 23\%, OB-E vs. OB-NE - $12 \%$ ), una reducción en el índice de adiposidad (MA-E vs. MA-NE -49\%, OB-E vs. OB-NE -24 \%) y en el hígado una disminución de la esteatosis (MA-E vs. MA-NE -57\%, OB-E vs. OB-NE -77 \%). Estos cambios metabólicos caracterizan una actuación beneficiosa del protocolo de EIAI en la natación. El EIAI es capaz de mitigar los efectos negativos causados por la dieta alta en grasas, incluso con la ingesta continuada de esta dieta en el modelo animal. La EIAI tiene la ventaja de requir sólo unas pocas sesiones semanales con corta duración de cada sesión. Estos beneficios son importantes para motivar a la personas en las condiciones de falta de tiempo que tienen en la actualidad.

PALABRAS CLAVE: Entrenamiento con intervalos de alta intensidad; Obesidad; Resistencia a la insulina; Esteatosis hepática; Estereología.

\section{REFERENCES}

Aguila, M. B.; Pinheiro Ada, R.; Parente, L. B. \& Mandarim-deLacerda, C. A. Dietary effect of different high-fat diet on rat liver stereology. Liver Int., 23(5):363-70, 2003.

Ahmadizad, S.; Avansar, A. S.; Ebrahim, K.; Avandi, M. \& Ghasemikaram, M. The effects of short-term high-intensity interval training vs. moderate-intensity continuous training on plasma levels of nesfatin-1 and inflammatory markers. Horm. Mol. Biol. Clin. Investig., 21(3):165-73, 2015.

Angadi, S. S.; Mookadam, F.; Lee, C. D.; Tucker, W. J.; Haykowsky, M. J. \& Gaesser, G. A. High-intensity interval training vs. moderate-intensity continuous exercise training in heart failure with preserved ejection fraction: a pilot study. J. Appl. Physiol. (1985), 119(6):753-8, 2014. 
Aucott, L.; Poobalan, A.; Smith, W. C.; Avenell, A.; Jung, R.; Broom, J. \& Grant, A. M. Weight loss in obese diabetic and non-diabetic individuals and long-term diabetes outcomes a systematic review. Diabetes Obes. Metab., 6(2):85-94, 2004.

Barbosa-da-Silva, S.; Fraulob-Aquino, J. C.; Lopes, J. R.; Mandarim-de-Lacerda, C. A. \& Aguila, M. B. Weight cycling enhances adipose tissue inflammatory responses in male mice. PLoS One, 7(7):e39837, 2012.

Bassuk, S. S. \& Manson, J. E. Epidemiological evidence for the role of physical activity in reducing risk of type 2 diabetes and cardiovascular disease. J. Appl. Physiol. (1985), 99(3):1193-204, 2005.

Catta-Preta, M.; Mendonca, L. S.; Fraulob-Aquino, J.; Aguila, M. B. \& Mandarim-de-Lacerda, C. A. A critical analysis of three quantitative methods of assessment of hepatic steatosis in liver biopsies. Virchows Arch., 459(5):477-85, 2011.

Centis, E.; Marzocchi, R.; Suppini, A.; Dalle Grave, R.; Villanova, N.; Hickman, I. J. \& Marchesini, G. The role of lifestyle change in the prevention and treatment of NAFLD. Curr. Pharm. Des., 19(29):5270-9, 2013.

Chrysohoou, C.; Angelis, A.; Tsitsinakis, G.; Spetsioti, S.; Nasis, I.; Tsiachris, D.; Rapakoulias, P.; Pitsavos, C.; Koulouris, N. G.; Vogiatzis, I. \& Dimitris, T. Cardiovascular effects of high-intensity interval aerobic training combined with strength exercise in patients with chronic heart failure. A randomized phase III clinical trial. Int. J. Cardiol., 179:26974, 2015.

Drigny, J.; Gremeaux, V.; Guiraud, T.; Gayda, M.; Juneau, M. \& Nigam, A. Long-term high-intensity interval training associated with lifestyle modifications improves QT dispersion parameters in metabolic syndrome patients. Ann. Phys. Rehabil. Med., 56(5):356-70, 2013.

El-Assaad, W.; Buteau, J.; Peyot, M. L.; Nolan, C.; Roduit, R.; Hardy, S.; Joly, E.; Dbaibo, G.; Rosenberg, L. \& Prentki, M. Saturated fatty acids synergize with elevated glucose to cause pancreatic beta-cell death. Endocrinology, 144(9):4154-63, 2003.

Fernandes-Santos, C.; Souza-Mello, V.; Faria, S. T. \& Mandarim-de-Lacerda, C.A. Quantitative morphology update: Image analysis. Int. J. Morphol., 31(1):23-30, 2013.

Ferrannini, E. Is insulin resistance the cause of the metabolic syndrome? Ann. Med., 38(1):42-51, 2006.

Fraulob, J. C.; Ogg-Diamantino, R.; Fernandes-Santos, C.; Aguila, M. B. \& Mandarim-de-Lacerda, C. A. A Mouse Model of Metabolic Syndrome: Insulin Resistance, Fatty Liver and Non-Alcoholic Fatty Pancreas Disease (NAFPD) in C57BL/ 6 Mice Fed a High Fat Diet. J. Clin. Biochem. Nutr., 46(3):212-23, 2010.
Gauthier, M. S.; Couturier, K.; Charbonneau, A. \& Lavoie, J. M. Effects of introducing physical training in the course of a 16week high-fat diet regimen on hepatic steatosis, adipose tissue fat accumulation, and plasma lipid profile. Int. J. Obes. Relat. Metab. Disord., 28(8):1064-71, 2004.

Gauthier, M. S.; Couturier, K.; Latour, J. G. \& Lavoie, J. M. Concurrent exercise prevents high-fat-diet-induced macrovesicular hepatic steatosis. J. Appl. Physiol. (1985), 94(6):2127-34, 2003.

Helge, J. W. Long-term fat diet adaptation effects on performance, training capacity, and fat utilization. Med. Sci. Sports Exerc., 34(9):1499-504, 2002.

Lamontagne, J.; Masiello, P.; Marcil, M.; Delghingaro-Augusto, V.; Burelle, Y.; Prentki, M. \& Nolan, C. J. Circulating lipids are lowered but pancreatic islet lipid metabolism and insulin secretion are unaltered in exercise-trained female rats. Appl. Physiol. Nutr. Metab., 32(2):241-8, 2007.

Little, J. P.; Gillen, J. B.; Percival, M. E.; Safdar, A.; Tarnopolsky, M. A.; Punthakee, Z.; Jung, M. E. \& Gibala, M. J. Low-volume high-intensity interval training reduces hyperglycemia and increases muscle mitochondrial capacity in patients with type 2 diabetes. J. Appl. Physiol. (1985), 111(6):1554-60, 2011.

Marques, C. M.; Motta, V. F.; Torres, T. S.; Aguila, M. B. \& Mandarim-de-Lacerda, C. A. Beneficial effects of exercise training (treadmill) on insulin resistance and nonalcoholic fatty liver disease in high-fat fed C57BL/6 mice. Braz. J. Med. Biol. Res., 43(5):467-75, 2010.

Mei, M.; Zhao, L.; Li, Q.; Chen, Y.; Huang, A.; Varghese, Z.; Moorhead, J. F.; Zhang, S.; Powis, S. H.; Li, Q. \& Ruan, X. Z. Inflammatory stress exacerbates ectopic lipid deposition in C57BL/6J mice. Lipids Health Dis., 10:110, 2011.

Motta, V. F.; Aguila, M. B. \& Mandarim-De-Lacerda, C. A. Highintensity interval training (swimming) significantly improves the adverse metabolism and comorbidities in diet-induced obese mice. J. Sports Med. Phys. Fitness, 2015. [Epub ahead of print]. Available from: http://www.minervamedica.it/en/ journals / s ports-med-physical-fitnes s / article.php?cod=R40Y9999N00A150034

Pimenta, M.; Bringhenti, I.; Souza-Mello, V.; Dos Santos Mendes, I. K.; Aguila, M. B. \& Mandarim-de-Lacerda, C. A. Highintensity interval training beneficial effects on body mass, blood pressure, and oxidative stress in diet-induced obesity in ovariectomized mice. Life Sci., 139:75-82, 2015.

Poobalan, A.; Aucott, L.; Smith, W. C.; Avenell, A.; Jung, R.; Broom, J. \& Grant, A. M. Effects of weight loss in overweight/ obese individuals and long-term lipid outcomes--a systematic review. Obes. Rev., 5(1):43-50, 2004.

Reeves, P. G.; Nielsen, F. H. \& Fahey, G. C. Jr. AIN-93 purified diets for laboratory rodents: final report of the American 
MOTTA, V. F.; AGUILA, M. B. \& MANDARIM-DE-LACERDA, C. A. High-intensity interval training beneficial effects in diet-induced obesity in mice: adipose tissue, liver structure, and pancreatic islets. Int. J. Morphol., 34(2):684-691, 2016

Institute of Nutrition ad hoc writing committee on the reformulation of the AIN-76A rodent diet. J. Nutr., 123(11):1939-51, 1993.

Scharf, M.; Schmid, A.; Kemmler, W.; von Stengel, S.; May, M. S.; Wuest, W.; Achenbach, S.; Uder, M. \& Lell, M. M. Myocardial adaptation to high-intensity (interval) training in previously untrained men with a longitudinal cardiovascular magnetic resonance imaging study (Running Study and Heart Trial). Circ. Cardiovasc. Imaging, 8(4):e002566, 2015.

Schrauwen, P. \& Westerterp, K. R. The role of high-fat diets and physical activity in the regulation of body weight. Br. J. Nutr., 84(4):417-27, 2000.

Schultz, A.; Mendonca, L. S.; Aguila, M. B. \& Mandarim-deLacerda, C. A. Swimming training beneficial effects in a mice model of nonalcoholic fatty liver disease. Exp. Toxicol. Pathol., 64(4):273-82, 2012.

Shamseddeen, H.; Getty, J. Z.; Hamdallah, I. N. \& Ali, M. R. Epidemiology and economic impact of obesity and type 2 diabetes. Surg. Clin. North Am., 91(6):1163-72, 2011.

Smith-Ryan, A. E.; Melvin, M. N. \& Wingfield, H. L. High-intensity interval training: Modulating interval duration in overweight/ obese men. Phys. Sportsmed, 43(2):107-13, 2015.

Tock, L.; Prado, W. L.; Caranti, D. A.; Cristofalo, D. M.; Lederman, H.; Fisberg, M.; Siqueira, K. O.; Stella, S. G.; Antunes, H. K.; Cintra, I. P.; Tufik, S.; de Mello, M. T. \& Dâmaso, A. R. Nonalcoholic fatty liver disease decrease in obese adolescents after multidisciplinary therapy. Eur. J. Gastroenterol. Hepatol., 18(12):1241-5, 2006

Tschanz, S. A.; Burri, P. H. \& Weibel, E. R. A simple tool for stereological assessment of digital images: the STEPanizer. $J$. Microsc., 243(1):47-59, 2011.

Weston, K. S.; Wisløff, U. \& Coombes, J. S. High-intensity interval training in patients with lifestyle-induced cardiometabolic disease: a systematic review and meta-analysis. Br. J. Sports Med., 48(16):1227-34, 2014.

Yang, X. \& Smith, U. Adipose tissue distribution and risk of metabolic disease: does thiazolidinedione-induced adipose tissue redistribution provide a clue to the answer? Diabetologia, 50(6):1127-39, 2007.
Younossi, Z. M. Review article: current management of nonalcoholic fatty liver disease and non-alcoholic steatohepatitis. Aliment. Pharmacol. Ther., 28(1):2-12, 2008.

Correspondence to:

Carlos A. Mandarim-de-Lacerda

Laboratorio de Morfometria,

Metabolismo e Doenca Cardiovascular

Centro Biomedico

Instituto de Biologia

Universidade do Estado do Rio de Janeiro.

Av. 28 de Setembro 87 (fds) 20551-030

Rio de Janeiro, RJ

BRAZIL

Phone: (+55 21) 2868.8316

FAX: 2868.8033

Email: mandarim@uerj.br

URL: www.Immc.uerj.br.

Received: 31-08-2015

Accepted: 29-02-2016 